\title{
ASSESSING THE RISK PERCEPTION OF COST OVERRUN THROUGH IMPORTANCE RATING
}

\author{
Murat GUNDUZ11, Omar Liqaa MAKI \\ Department of Civil Engineering, Qatar University, P.O. Box: 2713 Doha, Qatar
}

Received 27 July 2016; accepted 17 April 2017

\begin{abstract}
Cost overrun in construction projects is a common issue affecting project performance. After a review of the literature, a list of 39 cost overrun attributes were gathered and presented in a survey. The survey was distributed online to construction professionals. 101 complete responses were received and analyzed by importance index, frequency index, cost index, frequency adjusted cost index, Spearman's rank correlation, student's t-test, risk assessment and factor analysis. The results of the survey revealed that the main causes of cost overrun in construction industry include inaccurate cost estimation, improper planning and scheduling, unrealistic contract duration and requirements, frequent changes to the scope of work, frequent design changes, inadequate labor/ skill availability, inflation on costs of machinery, labor, material and transportation.
\end{abstract}

Keywords: risk assessment, cost overrun, importance index, frequency adjusted cost index.

JEL Classification: C83, L74, O22.

\section{Introduction}

Cost has its proven significance as the key factor for any project success. A completed project may not be considered as a successful endeavor unless it falls within the cost limitations applied to it. Despite its proven importance, it is very common to have a construction project that fails to achieve its specified cost goals. A lot of research has been performed to identify cost overrun attributes to improve the overall the construction industry performance (Azhar et al. 2008; Elchaig et al. 2005)

This study was conducted to identify and rank the major causes of cost overrun in construction sector and to compare responses obtained from professionals who work in various segments of the construction industry.

${ }^{\star}$ Corresponding author. E-mail: mgunduz@qu.edu.qa 


\section{Literature review}

Cost variance is one of the most important indicators of project success (Frimponga et al. 2003). It is not just a measure of the company's profitability but also the productivity of that organization at any time during the construction. Despite its proven importance, it is rare to see a project completed within the estimated cost (Azhar et al. 2008). In this study, a literature review on construction cost overrun attributes was performed to identify the most common factors that cause the cost overrun and to address the required measures to overcome and reduce them. Flyvbjerg et al. (2003) conducted a global study on cost overrun. This study covered 258 infrastructure projects in 20 nations and concluded that 9 out 10 projects faced cost overrun. Through an extensive literature review on cost overrun factors related to construction projects, a list of 39 cost overrun factors was collected to summarize all the factors found in the related literature. The collected factors helped in ranking the factors based on their importance, frequency and impact on cost of construction industry. Table 1 presents the 39 cost overrun attributes with their corresponding references.

Table 1. Cost overrun attributes

\begin{tabular}{|l|l|}
\hline \multicolumn{1}{|c|}{ Factors } & \multicolumn{1}{|c|}{ References } \\
\hline $\begin{array}{l}\text { Insufficient site management and } \\
\text { inspection }\end{array}$ & (Harisaweni 2007; Azhar et al. 2008) \\
\hline Schedule delay & (Harisaweni 2007; Omoregie 2006; Gunduz, Abuhassan 2017) \\
\hline $\begin{array}{l}\text { Improper planning and } \\
\text { scheduling }\end{array}$ & (Arcila 2012; Harisaweni 2007; Azhar et al. 2008) \\
\hline Improper monitoring and control & (Harisaweni 2007; Azhar et al. 2008; Frimponga et al. 2003) \\
\hline $\begin{array}{l}\text { Lack of experience in handling } \\
\text { construction projects }\end{array}$ & $\begin{array}{l}\text { (Enshassi } \text { et al. 2009; Sambasivan and Soon 2007; Chan, } \\
\text { Kumaraswamy 1997) }\end{array}$ \\
\hline $\begin{array}{l}\text { Delay in inspection and approval } \\
\text { of completed work }\end{array}$ & $\begin{array}{l}\text { (Assaf } \text { et al. 1995; Sambasivan, Soon 2007; Long } \text { et al. 2004; } \\
\text { Odeh, Battaineh 2002; Al-Kharashi, Skitmore 2008) }\end{array}$ \\
\hline Errors during construction & $\begin{array}{l}\text { (Assaf } \text { et al. 1995; Le-Hoai } \text { et al. 2008; Oludolapo 2011; } \\
\text { Sambasivan, Soon 2007; Odeh, Battaineh 2002; Tumi } \text { et al. } \\
\text { 2009; Al-Tabtabai 2002) }\end{array}$ \\
\hline Accidents on site & $\begin{array}{l}\text { (Lo } \text { et al. 2006; Assaf } \text { et al. 1995; Tumi } \text { et al. 2009; El-Razek } \\
\text { et al. 2008) }\end{array}$ \\
\hline Effect of weather & $\begin{array}{l}\text { (Harisaweni 2007; Assaf } \text { et al. 1995; Sambasivan, Soon 2007; } \\
\text { Frimponga } \text { et al. 2003; Long } \text { et al. 2004; Lo } \text { et al. 2006; Odeh, } \\
\text { Battaineh 2002) }\end{array}$ \\
\hline Unforeseen ground conditions & $\begin{array}{l}\text { (Sambasivan, Soon 2007; Le-Hoai } \text { et al. 2008; Chan, } \\
\text { Kumaraswamy 1997; Long } \text { et al. 2004; Lo et al. 2006; Odeh, } \\
\text { Battaineh 2002) }\end{array}$ \\
\hline Frequent Design changes & $\begin{array}{l}\text { (Arcila 2012; Harisaweni 2007; Azhar } \text { et al. 2008; Omoregie } \\
\text { 2006; Enshassi } \text { et al. 2009; Frimponga } \text { et al. 2003) }\end{array}$ \\
\hline Design errors and mistakes & $\begin{array}{l}\text { (Shibani, Arumugam 2015; Assaf } \text { et al. 1995; Tumi } \text { et al. } \text { 2009; } \\
\text { El-Razek } \text { et al. 2008; Sweis } \text { et al. 2008; Le-Hoai } \text { et al. 2008) }\end{array}$ \\
\hline $\begin{array}{l}\text { Incomplete design at time of } \\
\text { tender }\end{array}$ & (Azhar et al. 2008; Enshassi et al. 2009) \\
\hline
\end{tabular}


Continue of Table 1

\begin{tabular}{|c|c|}
\hline Factors & References \\
\hline $\begin{array}{l}\text { Deficient design and delays in } \\
\text { design process }\end{array}$ & (Assaf et al. 1995; Fugar, Agyakwah-Baah 2010) \\
\hline Delay in approval of drawings & $\begin{array}{l}\text { (Omoregie 2006; Sambasivan, Soon 2007; Assaf et al. 1995; } \\
\text { Odeh, Battaineh 2002; Al-Kharashi, Skitmore 2008; El-Razek } \\
\text { et al. 2008; Aibinu, Odeyinka 2006). }\end{array}$ \\
\hline $\begin{array}{l}\text { Delay in progress payment by } \\
\text { owner for work completed }\end{array}$ & $\begin{array}{l}\text { (Arcila 2012; Azhar et al. 2008; Frimponga et al. 2003; Assaf } \\
\text { et al. 1995; Odeh, Battaineh 2002; Al-Kharashi, Skitmore 2008; } \\
\text { El-Razek et al. 2008; Sweis et al. 2008) }\end{array}$ \\
\hline Financial difficulties of owner & $\begin{array}{l}\text { (Moura et al. 2007; Azhar et al. 2008; Le-Hoai et al. 2008; } \\
\text { Frimponga et al. 2003; Long et al. 2004; Sweis et al. 2008) }\end{array}$ \\
\hline $\begin{array}{l}\text { Cash flow difficulties faced by } \\
\text { contractor }\end{array}$ & $\begin{array}{l}\text { (Azhar et al. 2008; Moura et al. 2007; Frimponga et al. 2003; } \\
\text { Assaf et al. 1995; Sambasivan, Soon 2007; Long et al. 2004; } \\
\text { Tumi et al. 2009; Sweis et al. 2008) }\end{array}$ \\
\hline Poor financial control on site & (Azhar et al. 2008; Oludolapo 2011) \\
\hline $\begin{array}{l}\text { Delay payment to supplier / } \\
\text { subcontractor }\end{array}$ & (Omoregie 2006; Sweis et al. 2008; Moura et al. 2007) \\
\hline $\begin{array}{l}\text { Weak communication between } \\
\text { project parties }\end{array}$ & $\begin{array}{l}\text { (Azhar et al. 2008; Arcila 2012; Enshassi et al. 2009; Assaf et al. } \\
\text { 1995; Sambasivan, Soon 2007; Chan, Kumaraswamy 1997; } \\
\text { Long et al. 2004) }\end{array}$ \\
\hline $\begin{array}{l}\text { Weak coordination between } \\
\text { project parties }\end{array}$ & $\begin{array}{l}\text { (Assaf et al. 1995; Lo et al. 2006; Sweis et al. 2008; El-Razek } \\
\text { et al. 2008) }\end{array}$ \\
\hline $\begin{array}{l}\text { Weak collaboration between } \\
\text { management and labor }\end{array}$ & (Long et al. 2004; El-Razek et al. 2008) \\
\hline Disputes on site & $\begin{array}{l}\text { (Assaf et al. 1995; Odeh, Battaineh 2002; Al-Kharashi, Skitmore } \\
\text { 2008; Sambasivan, Soon 2007) }\end{array}$ \\
\hline Low labor productivity & $\begin{array}{l}\text { (Harisaweni 2007; Moura et al. 2007; Chan, Kumaraswamy } \\
\text { 1997; Assaf et al. 1995; Odeh, Battaineh 2002; Al-Tabtabai } \\
\text { 2002) }\end{array}$ \\
\hline $\begin{array}{l}\text { Lack and shortage of skilled } \\
\text { labors }\end{array}$ & $\begin{array}{l}\text { (Harisaweni 2007; Azhar et al. 2008; Frimponga et al. 2003; } \\
\text { Shibani, Arumugam 2015; Moura et al. 2007; Assaf et al. 1995; } \\
\text { Lo et al. 2006) }\end{array}$ \\
\hline Inflation in the cost of labors & (Azhar et al. 2008) \\
\hline Fluctuation in raw material prices & $\begin{array}{l}\text { (Azhar et al. 2008; Omoregie 2006; Enshassi et al. 2009; } \\
\text { Frimponga et al. 2003; Shibani, Arumugam 2015) }\end{array}$ \\
\hline $\begin{array}{l}\text { Late delivery of materials and } \\
\text { equipment }\end{array}$ & $\begin{array}{l}\text { (Arcila 2012; Harisaweni 2007; Azhar et al. 2008; Omoregie } \\
\text { 2006; Frimponga et al. 2003; Shibani, Arumugam 2015; Moura } \\
\text { et al. 2007; Assaf et al. 1995; Tumi et al. 2009) }\end{array}$ \\
\hline Insufficient number of equipment & $\begin{array}{l}\text { (Harisaweni 2007; Assaf et al. 1995; Al-Kharashi, Skitmore } \\
\text { 2008; El-Razek et al. 2008; Sweis et al. 2008; Aibinu, } \\
\text { Odeyinka 2006) }\end{array}$ \\
\hline $\begin{array}{l}\text { Changes in material specs and } \\
\text { types }\end{array}$ & $\begin{array}{l}\text { (Harisaweni 2007; Assaf et al. 1995; Al-Kharashi, Skitmore } \\
\text { 2008; El-Razek et al. 2008; Sweis et al. 2008) }\end{array}$ \\
\hline Poor project management & $\begin{array}{l}\text { (Arcila 2012; Azhar et al. 2008; Shibani, Arumugam 2015; } \\
\text { Tumi et al. 2009; Le-Hoai et al. 2008; Sinesilassie et al. 2017; } \\
\text { Yousefi et al. 2016) }\end{array}$ \\
\hline
\end{tabular}


End of Table 1

\begin{tabular}{|l|l|}
\hline \multicolumn{1}{|c|}{ Factors } & \multicolumn{1}{|c|}{ References } \\
\hline $\begin{array}{l}\text { Frequent changes to the scope of } \\
\text { work }\end{array}$ & $\begin{array}{l}\text { (Harisaweni 2007; Azhar } \text { et al. 2008; Enshassi } \text { et al. 2009; } \\
\text { Frimponga } \text { et al. 2003; Moura } \text { et al. 2007; Lo } \text { et al. 2006; } \\
\text { Assaf } \text { et al. 1995) }\end{array}$ \\
\hline Delays in decisions making & $\begin{array}{l}\text { (Enshassi } \text { et al. 2009; Frimponga } \text { et al. 2003; Assaf } \text { et al. 1995; } \\
\text { Sambasivan, Soon 2007; Chan, Kumaraswamy 1997; Long } \text { et al. } \\
\text { 2004; Odeh, Battaineh 2002) }\end{array}$ \\
\hline Poor contract management & $\begin{array}{l}\text { (Sambasivan, Soon 2007; Long } \text { et al. 2004; Odeh, Battaineh } \\
\text { 2002; Le-Hoai } \text { et al. 2008) }\end{array}$ \\
\hline Errors in contract documents & $\begin{array}{l}\text { (Sambasivan, Soon 2007; Lo } \text { et al. 2006; Assaf } \text { et al. 1995; Odeh, } \\
\text { Battaineh 2002; Al-Kharashi, Skitmore 2008; Tumi } \text { et al. 2009) }\end{array}$ \\
\hline $\begin{array}{l}\text { Unrealistic contract duration and } \\
\text { requirements imposed }\end{array}$ & $\begin{array}{l}\text { (Sambasivan, Soon 2007; Chan, Kumaraswamy 1997; } \\
\text { Long } \text { et al. 2004; Lo et al. 2006; Assaf } \text { et al. 1995; Odeh, } \\
\text { Battaineh 2002; Al-Kharashi, Skitmore 2008) }\end{array}$ \\
\hline Owner interference & $\begin{array}{l}\text { (Sambasivan, Soon 2007; Long } \text { et al. 2004; Assaf } \text { et al. 1995; } \\
\text { Sweis } \text { et al. 2008; Yates 1993) }\end{array}$ \\
\hline $\begin{array}{l}\text { Inaccurate time and cost } \\
\text { estimates of project }\end{array}$ & $\begin{array}{l}\text { (Harisaweni 2007; Omoregie 2006; Frimponga et al. 2003; } \\
\text { Le-Hoai } \text { et al. 2008; Long } \text { et al. 2004; Yates 1993) }\end{array}$ \\
\hline
\end{tabular}

\section{Methodology}

This study was based on reviewing past literature to come up with a summarized list of cost overrun attributes affecting construction projects. A survey has been distributed on construction industry experts to rank the 39 attributes based on importance, frequency and impact on cost. The survey contains two sections: 1) Respondents information: To categorize the respondents into different groups for the purpose of comparisons. Cost overrun attributes evaluation: Composed of the 39 cost overrun attributes affecting construction projects. These 39 factors can be seen in Table 1 . The respondents were requested to evaluate the "importance" (The impact of this factor on cost overrun in construction project), "frequency" (How often the attribute is implemented or considered) and "Impact on Cost Overrun" (What is the direct impact of this factor on the cost overrun) on a 5 point Likert Scale $(1=$ Very Low, 2 = Low, 3 = Moderate, 4 = high, 5 = Very High). For an example, for the first cause of cost overrun factors" insufficient site management and inspection", the respondent was asked to evaluate the: The factors have been ranked as perceived by various groups of industry professionals. The survey was sent to numerous contacts that play key roles in the construction industry worldwide. A total of 101 completed surveys were received. A comparison between respondents' rankings was applied based on their location, organization type, job designation, industry type, total construction experience, and size of their companies. Results were discussed and analyzed based on various statistical analyses methods such as: importance index, frequency index, cost impact index, frequency adjusted cost index, Spearman's rank correlation, T-test and risk assessment matrices. Those results have been used to generate recommendations to industry firms and professionals. 


\section{Data characteristics}

The survey has been developed using an online website. The website was used in distributing the survey and collecting the responses. 101 complete responses were selected to be the base of the analysis. For the organization type, contractors were the largest contributors to the survey with $41.2 \%$ of responses, while consultants were the second forming almost $18 \%$ of the total participants as shown in Figure 1. 37.5\% of the respondents were project or construction managers, $23.8 \%$ of them were project engineers, $17.5 \%$ of them were resident engineers, $16.3 \%$ were site engineers and $5 \%$ were owners. $46.1 \%$ of the respondents indicated their major industry type as superstructure whereas $37.1 \%$ indicated as infrastructure. The percentages for industrial and oil gas sectors were $12.4 \%$ and $4.5 \%$ respectively. Respondents were also classified based on total years of work experiences in construction. Of the 101 participants, $33.7 \%$ of them are professionals with more than 16 years of experience in construction industry. The respondents who work in superstructure projects formed the majority of participants with a rate of $46.1 \%$, followed by infrastructure construction projects with a rate of $37.1 \%$. Respondents were also classified based on their company sizes which are either large companies with more than 250 employees, medium companies with 50 to 250 employees or small companies which have less than 50 employees. Majority of respondents fall into the category of large company size with a percentage of $59 \%$, followed by a medium size company which is $29 \%$ of the respondents.

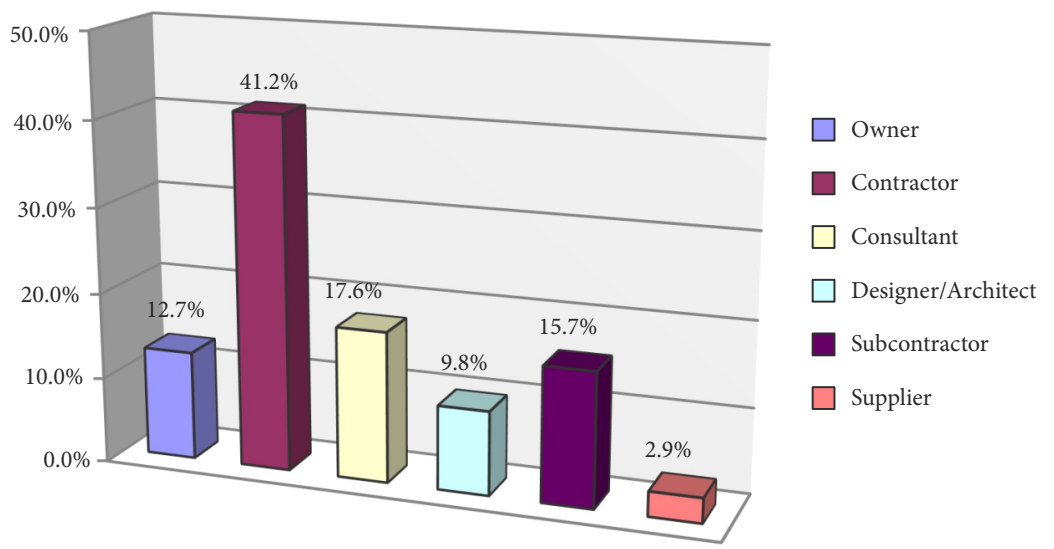

Figure 1. Percentage of respondents based on organization type

\section{Data analysis}

One of the objectives of this research is to identify the influencing cost overrun attributes based on point of views of the construction industry professionals. Survey participants used a 5 - point Likert Scale to rate each individual cost overrun factor's importance, frequency and impact on cost. The ratings of the scale are 1 (very low), 2 (low), 3 (moderate), 4 (high), and 5 (very high). The importance was rated to measure the impact of the factor on the cost of the construction project, while the frequency was used to determine how often the attribute 
occurs in construction projects, and the impact on cost was used to assess the effect of that particular attribute.

Importance index, Spearman's rank correlation, $\mathrm{t}$-test and risk assessment were used to analyze the results. The data analysis is explained in the coming sections.

\subsection{Frequency Cost Adjusted Importance Index (FCAII)}

The Frequency-Cost Adjusted Importance Index (FCAII) is an inventive ranking approach adopted in this research to rank cost overrun attributes in construction industry. This technique considers the importance, the frequency and the cost impact in its formula. In order to find the FCAII, the Relative Importance Index (RII), the Frequency Index (FI) and the Cost Impact Index (CII) are required to be measured and calculated referring to data collected from the survey. The equations for RII, FI and CII are shown in Eq. (1), Eq. (2) and Eq. (3):

$$
\begin{aligned}
& \mathrm{RII}(\%)=\frac{\sum \mathrm{Wi}^{\star} \mathrm{Xi}}{\mathrm{A}(\mathrm{N})} \times 100 ; \\
& \mathrm{FI}(\%)=\frac{\sum \mathrm{Wi}^{\star} \mathrm{Xi}}{\mathrm{A}(\mathrm{N})} \times 100 ; \\
& \mathrm{CII}(\%)=\frac{\sum \mathrm{Wi}^{\star} \mathrm{Xi}}{\mathrm{A}(\mathrm{N})} \times 100,
\end{aligned}
$$

where: $\mathrm{W}$ - weighting given to each factor by respondents and it ranges from 1 to 5 ; $\mathrm{X}-$ frequency of ith response given for each cause; $\mathrm{A}$ - highest weight (i.e. 5 in this case); $\mathrm{N}$ - total number of participants (i.e. 101 in this research)

Based on the RII, FI and CII equations, the frequency cost adjusted importance index will be calculated as follows:

$$
\mathrm{FCAII}=(\mathrm{RII} \times \mathrm{FI} \times \mathrm{CII}) .
$$

FCAII reflect the effects of importance, frequency and cost impact all together and hence it provides better ranking results.

Table 2 below shows RII, FI, CII and FCAII values in addition to the FCAII rankings of all the participants.

Table 2. RII, FI, CII and FCAII (values and rankings) of cost overrun attributes by all respondents.

\begin{tabular}{|c|l|c|c|c|c|c|}
\hline Category & \multicolumn{1}{|c|}{ Factor } & RI & FI & CII & FCAII & Rank \\
\hline CPH & Schedule delay & 0.820 & 0.693 & 0.824 & 0.47 & 1 \\
\hline CPH & Improper planning and scheduling & 0.865 & 0.653 & 0.826 & 0.47 & 2 \\
\hline D & Frequent Design changes & 0.871 & 0.606 & 0.844 & 0.45 & 3 \\
\hline PM & Frequent changes to the scope of work & 0.844 & 0.608 & 0.836 & 0.43 & 4 \\
\hline PM & Inaccurate time and cost estimates of project & 0.853 & 0.614 & 0.808 & 0.42 & 5 \\
\hline PM & $\begin{array}{l}\text { Unrealistic contract duration and } \\
\text { requirements imposed }\end{array}$ & 0.869 & 0.586 & 0.830 & 0.42 & 6 \\
\hline
\end{tabular}


End of Table 2

\begin{tabular}{|c|c|c|c|c|c|c|}
\hline Category & Factor & RI & FI & CII & FCAII & Rank \\
\hline PM & Poor project management & 0.871 & 0.588 & 0.802 & 0.41 & 7 \\
\hline $\mathrm{PM}$ & Delays in decisions making & 0.818 & 0.602 & 0.739 & 0.36 & 8 \\
\hline $\mathrm{L}$ & Lack and shortage of skilled labors & 0.810 & 0.636 & 0.699 & 0.36 & 9 \\
\hline $\mathrm{F}$ & $\begin{array}{l}\text { Delay in progress payment by owner for work } \\
\text { completed }\end{array}$ & 0.826 & 0.612 & 0.711 & 0.36 & 10 \\
\hline $\mathrm{CPH}$ & Improper monitoring and control & 0.768 & 0.602 & 0.768 & 0.36 & 11 \\
\hline $\mathrm{D}$ & Incomplete design at time of tender & 0.798 & 0.550 & 0.790 & 0.35 & 12 \\
\hline $\mathrm{F}$ & Cash flow difficulties faced by contractor & 0.794 & 0.584 & 0.717 & 0.33 & 13 \\
\hline $\mathrm{PM}$ & Errors in contract documents & 0.808 & 0.531 & 0.770 & 0.33 & 14 \\
\hline $\mathrm{L}$ & Low labor productivity & 0.794 & 0.582 & 0.707 & 0.33 & 15 \\
\hline PM & Poor contract management & 0.762 & 0.588 & 0.727 & 0.33 & 16 \\
\hline $\mathrm{M} \& \mathrm{E}$ & Fluctuation in raw material prices & 0.816 & 0.552 & 0.719 & 0.32 & 17 \\
\hline $\mathrm{F}$ & Delay payment to supplier /subcontractor & 0.762 & 0.606 & 0.701 & 0.32 & 18 \\
\hline $\mathrm{CPH}$ & Insufficient site management and inspection & 0.747 & 0.598 & 0.725 & 0.32 & 19 \\
\hline $\mathrm{M} \& \mathrm{E}$ & Late delivery of materials and equipment & 0.784 & 0.596 & 0.681 & 0.32 & 20 \\
\hline $\mathrm{D}$ & Design errors and mistakes & 0.798 & 0.513 & 0.768 & 0.31 & 21 \\
\hline $\mathrm{CPH}$ & $\begin{array}{l}\text { Lack of experience in handling construction } \\
\text { projects }\end{array}$ & 0.731 & 0.584 & 0.729 & 0.31 & 22 \\
\hline $\mathrm{M} \& \mathrm{E}$ & Changes in material specs and types & 0.749 & 0.572 & 0.721 & 0.31 & 23 \\
\hline $\mathrm{F}$ & Poor financial control on site & 0.752 & 0.558 & 0.725 & 0.30 & 24 \\
\hline $\mathrm{F}$ & Financial difficulties of owner & 0.816 & 0.493 & 0.747 & 0.30 & 25 \\
\hline $\mathrm{C}$ & Weak communication between project parties & 0.756 & 0.576 & 0.683 & 0.30 & 26 \\
\hline $\mathrm{C}$ & Weak coordination between project parties & 0.770 & 0.578 & 0.663 & 0.30 & 27 \\
\hline $\mathrm{D}$ & Deficient design and delays in design process & 0.762 & 0.529 & 0.719 & 0.29 & 28 \\
\hline $\mathrm{D}$ & Delay in approval of drawings & 0.727 & 0.586 & 0.667 & 0.28 & 29 \\
\hline $\mathrm{CPH}$ & $\begin{array}{l}\text { Delay in inspection and approval of } \\
\text { completed work }\end{array}$ & 0.669 & 0.632 & 0.663 & 0.28 & 30 \\
\hline $\mathrm{CPH}$ & Errors during construction & 0.707 & 0.572 & 0.693 & 0.28 & 31 \\
\hline PM & Owner interference & 0.721 & 0.566 & 0.646 & 0.26 & 32 \\
\hline $\mathrm{L}$ & Inflation in the cost of labors & 0.739 & 0.507 & 0.701 & 0.26 & 33 \\
\hline $\mathrm{M} \& \mathrm{E}$ & Insufficient number of equipment & 0.671 & 0.550 & 0.636 & 0.23 & 34 \\
\hline $\mathrm{C}$ & $\begin{array}{l}\text { Weak collaboration between management and } \\
\text { labor }\end{array}$ & 0.677 & 0.549 & 0.596 & 0.22 & 35 \\
\hline $\mathrm{CPH}$ & Accidents on site & 0.741 & 0.418 & 0.663 & 0.21 & 36 \\
\hline $\mathrm{C}$ & Disputes on site & 0.628 & 0.513 & 0.584 & 0.19 & 37 \\
\hline $\mathrm{CPH}$ & Unforeseen ground conditions & 0.578 & 0.400 & 0.547 & 0.13 & 38 \\
\hline $\mathrm{CPH}$ & Effect of weather & 0.497 & 0.430 & 0.446 & 0.10 & 39 \\
\hline
\end{tabular}


Where code $\mathrm{CPH}$ stands for construction phase factors, $\mathrm{D}$ is Design factors, $\mathrm{F}$ is Finance factors, $\mathrm{C}$ is Communication factors, $\mathrm{L}$ is Labor factors, M\&E is Material and Equipment factors, and PM is Project Management factors

From Table 2, it can be seen that the top 5 ranked cost overrun factors based on FCAII values are: 1) Schedule delay; 2) Improper planning and scheduling; 3) Frequent Design changes; 4) Frequent changes to the scope of work; 5) Inaccurate time and cost estimates of project.

\subsection{Ranking comparison amongst respondents}

The Spearman's rank correlation coefficient $(\rho)$ was used to show the degree of agreement between the rankings of any two parties. The formula is as follows:

$$
\rho=1-\frac{6 \sum d^{2}}{N^{3}-N},
$$

where, $\rho$ - Spearman rank correlation coefficient between two parties; $d$ - difference between ranks assigned to variables for each cause;. $n$ - the number of attributes which is 39 .

The Spearman's correlation assesses relationship between different parties regarding different factors strength. In this research, it has been used in comparing responses based on location, organization type, job designation etc. According to the definition of its formula, the correlation coefficient varies between +1 and -1 , where +1 implies a perfect positive relationship (agreement), while -1 results from a perfect negative relationship (disagreement). Assumption of no multi-collinearity between attributes was made.

Nine comparisons were conducted: Contractor vs. consultant, Contractor vs. Subcontractor, Contractor vs. Owner, Owner vs. consultant, Project / Construction manager vs. Project Engineer, Superstructure vs. Infrastructure, Superstructure vs. all others, Large ( $>250 \mathrm{em}-$ ployees) vs. Medium ( $50<$ employees < 250), Over 16 years vs. ALL Less than 16

Spearman's rank correlation factors for the above-mentioned comparisons are presented in Table 3. It can be seen from the Table 3 that the agreement level between various groups of respondents range from $0.60-0.79$.

Table 3. Ranking comparison amongst respondents

\begin{tabular}{|l|c|}
\hline \multicolumn{1}{|c|}{ Groups Compared } & Spearman's rank correlation factors \\
\hline Contractors vs. Consultants & 0.77 \\
\hline Contractors vs. Subcontractors & 0.79 \\
\hline Contractor vs. Owner & 0.60 \\
\hline Owner vs. consultant & 0.68 \\
\hline Project managers vs. Project Engineers & 0.61 \\
\hline Superstructure vs. Infrastructure & 0.62 \\
\hline Superstructure vs. all others & 0.79 \\
\hline Over 16 years experience vs. Less than 16 years experience & 0.74 \\
\hline Large (>250 employees) vs. Medium $(50<$ employees $<250)$ & 0.71 \\
\hline
\end{tabular}




\subsection{T-test}

T-test is a tool which is used to statistically identify if there is any significant difference between two independent categories groups. In this research, T-test is used to identify which cost overrun attributes has significant level of disagreement among the independent set of groups. Probability (p) value less than 0.1 shows a significant disagreement. Table 4 show the results of the T-test which represent significant disagreement among various groups based on location, job designation, organization type, industry type, total construction experience, and size of the company.

Table 4. T-test results

\begin{tabular}{|c|c|c|}
\hline Code & Attributes & T-Test (p) \\
\hline \multicolumn{3}{|c|}{ Project Managers vs. Project Engineers } \\
\hline $\mathrm{CPH}$ & Schedule delay & 0.0338 \\
\hline $\mathrm{CPH}$ & Improper monitoring and control & 0.0061 \\
\hline $\mathrm{CPH}$ & Delay in inspection and approval of completed work & 0.0257 \\
\hline $\mathrm{CPH}$ & Accidents on site & 0.0627 \\
\hline $\mathrm{C}$ & Weak coordination between project parties & 0.0179 \\
\hline $\mathrm{L}$ & Low labor productivity & 0.0879 \\
\hline $\mathrm{L}$ & Lack and shortage of skilled labors & 0.0514 \\
\hline PM & Delays in decisions making & 0.0651 \\
\hline \multicolumn{3}{|c|}{ Superstructure vs. Infrastructure } \\
\hline $\mathrm{CPH}$ & Schedule delay & 0.0454 \\
\hline $\mathrm{CPH}$ & Unforeseen ground conditions & 0.0841 \\
\hline $\mathrm{F}$ & Delay payment to supplier/subcontractor & 0.0122 \\
\hline $\mathrm{L}$ & Lack and shortage of skilled labors & 0.0825 \\
\hline $\mathrm{L}$ & Inflation in the cost of labors & 0.0672 \\
\hline M\&E & Changes in material specs and types & 0.0058 \\
\hline PM & Errors in contract documents & 0.0180 \\
\hline \multicolumn{3}{|c|}{ More than 16 years experience vs. less than 16 years experience } \\
\hline $\mathrm{CPH}$ & Insufficient site management and inspection & 0.0735 \\
\hline $\mathrm{CPH}$ & Schedule delay & 0.0001 \\
\hline $\mathrm{CPH}$ & Improper monitoring and control & 0.0804 \\
\hline $\mathrm{CPH}$ & Accidents on site & 0.0024 \\
\hline $\mathrm{D}$ & Delay in approval of drawings & 0.0735 \\
\hline $\mathrm{L}$ & Inflation in the cost of labors & 0.0172 \\
\hline M\&E & Fluctuation in raw material prices & 0.0067 \\
\hline PM & Errors in contract documents & 0.0328 \\
\hline \multicolumn{3}{|c|}{ Large Companies vs. Medium Companies } \\
\hline $\mathrm{CPH}$ & Insufficient site management and inspection & 0.0707 \\
\hline $\mathrm{CPH}$ & Improper monitoring and control & 0.0011 \\
\hline
\end{tabular}


Continue of Table 4

\begin{tabular}{|c|c|c|}
\hline Code & Attributes & T-Test $(\mathrm{p})$ \\
\hline $\mathrm{CPH}$ & Lack of experience in handling construction projects & 0.0511 \\
\hline $\mathrm{CPH}$ & Accidents on site & 0.0001 \\
\hline $\mathrm{CPH}$ & Effect of weather & 0.0595 \\
\hline $\mathrm{D}$ & Frequent Design changes & 0.0105 \\
\hline $\mathrm{D}$ & Incomplete design at time of tender & 0.0111 \\
\hline $\mathrm{D}$ & Delay in approval of drawings & 0.0804 \\
\hline $\mathrm{F}$ & Delay in progress payment by owner for work completed & 0.0000 \\
\hline $\mathrm{F}$ & Financial difficulties of owner & 0.0000 \\
\hline $\mathrm{F}$ & Cash flow difficulties faced by contractor & 0.0026 \\
\hline $\mathrm{F}$ & Poor financial control on site & 0.0007 \\
\hline $\mathrm{F}$ & Delay payment to supplier/subcontractor & 0.0001 \\
\hline $\mathrm{L}$ & Inflation in the cost of labors & 0.0000 \\
\hline $\mathrm{M} \& \mathrm{E}$ & Fluctuation in raw material prices & 0.0001 \\
\hline $\mathrm{M} \& \mathrm{E}$ & Late delivery of materials and equipment & 0.0095 \\
\hline $\mathrm{M} \& \mathrm{E}$ & Insufficient number of equipment & 0.0062 \\
\hline $\mathrm{M} \& \mathrm{E}$ & Changes in material specs and types & 0.0273 \\
\hline PM & Frequent changes to the scope of work & 0.0046 \\
\hline PM & Delays in decisions making & 0.0012 \\
\hline PM & Poor contract management & 0.0015 \\
\hline PM & Errors in contract documents & 0.0002 \\
\hline $\mathrm{PM}$ & Unrealistic contract duration and requirements imposed & 0.0065 \\
\hline \multicolumn{3}{|c|}{ GC vs. Owner } \\
\hline $\mathrm{CPH}$ & Insufficient site management and inspection & 0.0082 \\
\hline $\mathrm{CPH}$ & Schedule delay & 0.0212 \\
\hline $\mathrm{CPH}$ & Improper planning and scheduling & 0.0250 \\
\hline $\mathrm{CPH}$ & Improper monitoring and control & 0.0095 \\
\hline $\mathrm{D}$ & Incomplete design at time of tender & 0.0718 \\
\hline $\mathrm{D}$ & Delay in approval of drawings & 0.0285 \\
\hline $\mathrm{F}$ & Financial difficulties of owner & 0.0086 \\
\hline $\mathrm{F}$ & Cash flow difficulties faced by contractor & 0.0974 \\
\hline $\mathrm{F}$ & Poor financial control on site & 0.0376 \\
\hline $\mathrm{L}$ & Lack and shortage of skilled labors & 0.0932 \\
\hline $\mathrm{M} \& \mathrm{E}$ & Fluctuation in raw material prices & 0.0021 \\
\hline PM & Poor project management & 0.0128 \\
\hline $\mathrm{PM}$ & Inaccurate time and cost estimates of project & 0.0418 \\
\hline \multicolumn{3}{|c|}{ GC vs. Consultant } \\
\hline $\mathrm{D}$ & Frequent Design changes & 0.0032 \\
\hline
\end{tabular}


Continue of Table 4

\begin{tabular}{|c|c|c|}
\hline Code & Attributes & T-Test (p) \\
\hline $\mathrm{C}$ & Weak coordination between project parties & 0.0186 \\
\hline$M \& E$ & Changes in material specs and types & 0.0840 \\
\hline $\mathrm{PM}$ & Frequent changes to the scope of work & 0.0594 \\
\hline PM & Delays in decisions making & 0.0520 \\
\hline $\mathrm{PM}$ & Poor contract management & 0.0443 \\
\hline $\mathrm{PM}$ & Unrealistic contract duration and requirements imposed & 0.0005 \\
\hline PM & Owner interference & 0.0253 \\
\hline $\mathrm{PM}$ & Inaccurate time and cost estimates of project & 0.0263 \\
\hline \multicolumn{3}{|c|}{ GC vs. Subcontractor } \\
\hline $\mathrm{CPH}$ & Lack of experience in handling construction projects & 0.0335 \\
\hline $\mathrm{CPH}$ & Errors during construction & 0.0220 \\
\hline $\mathrm{CPH}$ & Accidents on site & 0.0556 \\
\hline $\mathrm{D}$ & Frequent Design changes & 0.0165 \\
\hline $\mathrm{D}$ & Delay in approval of drawings & 0.0851 \\
\hline $\mathrm{F}$ & Delay in progress payment by owner for work completed & 0.0000 \\
\hline $\mathrm{F}$ & Financial difficulties of owner & 0.0404 \\
\hline $\mathrm{F}$ & Cash flow difficulties faced by contractor & 0.0230 \\
\hline $\mathrm{F}$ & Poor financial control on site & 0.0181 \\
\hline $\mathrm{F}$ & Delay payment to supplier/subcontractor & 0.0000 \\
\hline $\mathrm{C}$ & Disputes on site & 0.0782 \\
\hline $\mathrm{L}$ & Low labor productivity & 0.0422 \\
\hline $\mathrm{L}$ & Lack and shortage of skilled labors & 0.0444 \\
\hline $\mathrm{M} \& \mathrm{E}$ & Fluctuation in raw material prices & 0.0716 \\
\hline $\mathrm{M} \& \mathrm{E}$ & Late delivery of materials and equipment & 0.0000 \\
\hline $\mathrm{M} \& \mathrm{E}$ & Changes in material specs and types & 0.0003 \\
\hline $\mathrm{PM}$ & Frequent changes to the scope of work & 0.0100 \\
\hline PM & Delays in decisions making & 0.0059 \\
\hline $\mathrm{PM}$ & Poor contract management & 0.0014 \\
\hline $\mathrm{PM}$ & Unrealistic contract duration and requirements imposed & 0.0088 \\
\hline \multicolumn{3}{|c|}{ Owner vs. Consultant } \\
\hline $\mathrm{CPH}$ & Schedule delay & 0.0006 \\
\hline $\mathrm{CPH}$ & Improper planning and scheduling & 0.0301 \\
\hline $\mathrm{CPH}$ & Improper monitoring and control & 0.0586 \\
\hline $\mathrm{D}$ & Frequent Design changes & 0.0168 \\
\hline $\mathrm{D}$ & Incomplete design at time of tender & 0.0083 \\
\hline $\mathrm{D}$ & Delay in approval of drawings & 0.0016 \\
\hline $\mathrm{F}$ & Delay in progress payment by owner for work completed & 0.0509 \\
\hline
\end{tabular}


End of Table 4

\begin{tabular}{|c|l|c|}
\hline Code & \multicolumn{1}{|c|}{ Attributes } & T-Test (p) \\
\hline F & Financial difficulties of owner & 0.0161 \\
\hline C & Weak coordination between project parties & 0.0192 \\
\hline L & Inflation in the cost of labors & 0.0592 \\
\hline M\&E & Fluctuation in raw material prices & 0.0049 \\
\hline PM & Poor project management & 0.0179 \\
\hline PM & Frequent changes to the scope of work & 0.0048 \\
\hline PM & Delays in decisions making & 0.0755 \\
\hline PM & Poor contract management & 0.0866 \\
\hline PM & Unrealistic contract duration and requirements imposed & 0.0025 \\
\hline PM & Owner interference & 0.0266 \\
\hline PM & Inaccurate time and cost estimates of project & 0.0003 \\
\hline
\end{tabular}

\section{Risk assessment}

Risk assessment is used in order to improve the understanding of risks associated with each cost overrun factor, by illustrating the nature of impact of risks resulted from the attribute that is presented as a matrix. Risk assessment matrix is a visual tool used to present risk associated with cost overrun factors: importance, frequency and impact on cost. Data will be plotted on scatter plot chart using mean values of data from respondents. The mean values represent the whole data set for the study.

Figures 2, 3 and 4 below show visual representation of each attribute average value of mean importance vs. mean frequency, mean importance vs. mean impact on cost, mean frequency vs. mean impact. Only the construction phase factors are shown below as an example.
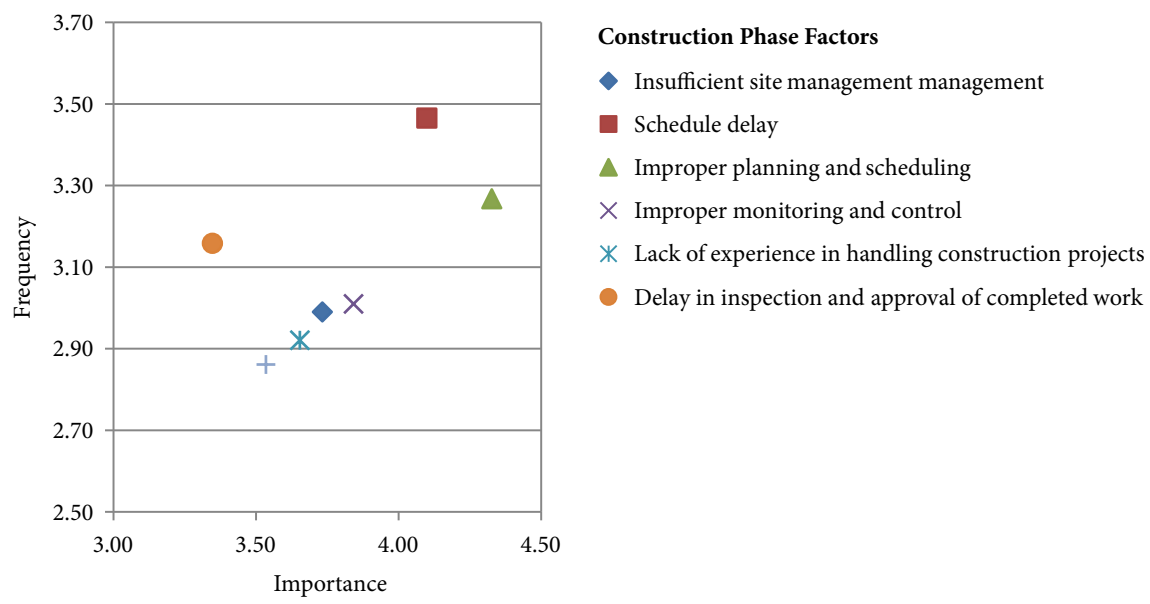

Figure 2. Risk matrix chart for cost overruns related to Construction Phase (Frequency vs. Importance) 


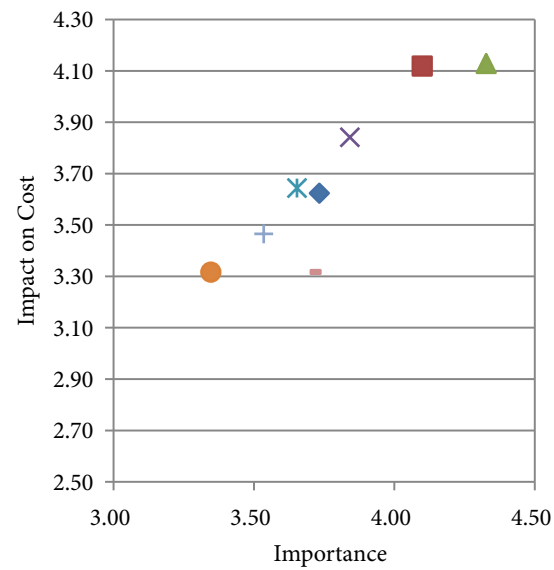

Construction Phase Factors

- Insufficient site management management

- Schedule delay

$\Delta$ Improper planning and scheduling

$X$ Improper monitoring and control

* Lack of experience in handling construction projects

- Delay in inspection and approval of completed work

Figure 3. Risk matrix chart for cost overruns related to Construction Phase (Impact on Cost vs. Importance)

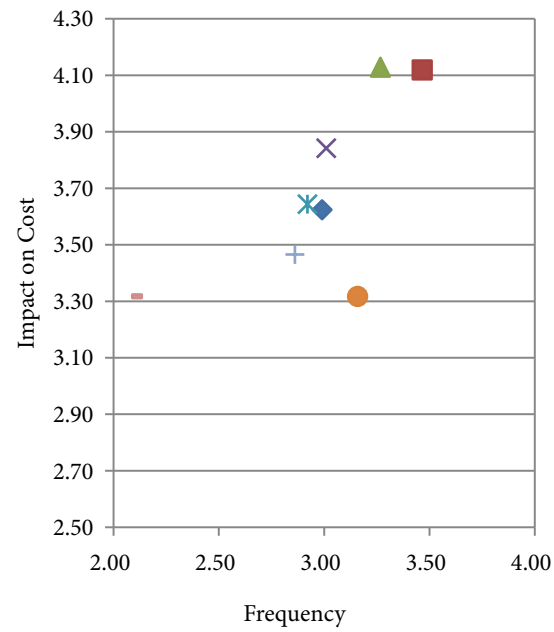

\section{Construction Phase Factors}

- Insufficient site management management

- Schedule delay

$\Delta$ Improper planning and scheduling

$X$ Improper monitoring and control

* Lack of experience in handling construction projects

- Delay in inspection and approval of completed work

Figure 4. Risk matrix chart for cost overruns related to Construction Phase (Impact on Cost vs. Frequency)

\section{Discussion of results}

The objective of this paper is to identify the most influential cost overrun attributes affecting the construction industry. After a review of past literature, a list of 39 cost overrun attributes was gathered and presented in a survey. The survey was distributed to various experts in the field of construction industry. 101 respondents evaluated the 39 cost overrun attributes based on importance (The cost overrun factor importance for a construction project), frequency (How often the attribute is implemented or considered) and the impact on cost (The extent of direct impact on project's cost overrun). The gathered data of 101 complete responses were then analyzed by importance index, Spearman's rank correlation, T-test, risk assessment. 
From Table 2, it can be concluded that the most significant cost overrun factor is the schedule delay (47\%). This overlaps with what have been reported by the past literature. The second most significant factor was the improper planning and scheduling (47\%). This shows that investing in hiring skilled planners and estimators will save the project from exceeding the budgeted cost.

Frequent design changes (45\%) and frequent changes to the scope of work (43\%) were observed as the third and fourth most significant factors. These factors have a major impact on any project, because even changing the design of a single beam in a whole building might affect the scope, the cost and the duration of the whole project. Moreover, design or scope change will require re-estimation of the cost and the schedule required to complete the project. All these would add additional costs to the project and therefore cause an overrun in the project.

Inaccurate time and cost estimates of project (42\%) was the fifth significant factor. This reflects the importance of hiring skilled and experienced planners and estimators in order to accurately estimate the required time and budget to complete the project.

\section{Conclusions}

Various researches were conducted to understand the factors affecting the construction projects cost overrun. This study focused on identifying the influential cost overrun attributes affecting construction industry. The contribution of the paper to the development of the stateof-the art in the topic is the extensive literature review to capture most significant factors that lead to cost overrun and analyzing them with various powerful statistical tools. 39 cost overrun attributes were collected based on literature review. In order to rank these attributes, an online survey was distributed among various professionals with various backgrounds, expertise, and locations. 101 respondents evaluated the 39 cost overrun attributes based on importance (The cost overrun factor importance for a construction project), frequency (How often the attribute is implemented or considered) and the impact on cost (The extent of direct impact on project's cost overrun).

Analysis of the survey results were performed by various statistical ranking tools such as relative importance index, frequency importance index, cost impact index, frequency-cost adjusted importance index, Spearman's rank correlation, T-Test, and risk assessment. According to the FCAII, the top three most significant cost overrun factors are schedule delay, improper planning and scheduling and frequent design changes. The conclusions of this research would help the construction professionals on mitigating the negative impact of the critical cost overrun factors. The results of the surveys can be generalized to all countries of the world easily by understanding the factors affecting the construction projects' cost overrun. The collected data and analysis makes it easy for the end users to rank top critical factors affecting cost overrun. These factors could be monitored with more attention to reduce cost overrun. 


\section{References}

Aibinu, A. A.; Odeyinka, H. A. 2006. Construction delays and their causative factors in Nigeria, Journal of Construction Engineering and Management 132(7): 667-677. https://doi.org/10.1061/(ASCE)0733-9364(2006)132:7(667)

Al-Kharashi, A.; Skitmore, M. 2008. Causes of delays in Saudi Arabian public sector construction projects, Construction Management and Economics 27(1): 3-23. https://doi.org/10.1080/01446190802541457

Al-Tabtabai, H. 2002. Causes for delays in construction projects in Kuwait, Engineering Journal of the University of Qatar (15): 19-37.

Arcila, S. 2012. Avoiding cost overruns in construction projects in the United Kingdom: Dissertation submitted in partial fulfilment for the Degree of Master of Science in Programme and Project Management. The University of Warwick.

Assaf, S. A.; Al-Khalid, M.; Al-Hazmi, M. 1995. Causes of delay in large building construction projects, Journal of Construction Engineering and Management, ASCE 11(2): 45-50. https://doi.org/10.1061/(ASCE)0742-597X(1995)11:2(45)

Azhar, N.; Farooqui, A.; Ahmed S. M. 2008. Cost overrun factors in construction industry of Pakistan, in 1st International Conference on Construction in Developing Countries (ICCIDC-I) Advancing and Integrating Construction Education, Research and Practice, 4-5 August 2008, Karachi, Pakistan, $1-10$.

Chan, D.; Kumaraswamy, M. 1997. A comparative study of causes of time overruns in Hong Kong construction projects, International Journal of Project Management 15(1): 55-63. https://doi.org/10.1016/S0263-7863(96)00039-7

El-Razek, M.; Bassioni, H; Mobarak, A. 2008. Causes of delay in building construction projects in Egypt, Journal of Construction Engineering and Management 134(11): 831-841. https://doi.org/10.1061/(ASCE)0733-9364(2008)134:11(831)

Elchaig, T.; Boussabinaine, A.; Ballal, T. 2005. Critical determinants of construction tendering costs: Quantity surveyors' standpoint, International Journal of Project Management 23(7): 538-545. https://doi.org/10.1016/j.ijproman.2005.04.002

Enshassi, A.; Al-Najjar, J.; Kumaraswamy, M. 2009. Delays and cost overruns in the construction projects in the Gaza Strip, Journal of Financial Management of Property and Construction 14(2): 126151. https://doi.org/10.1108/13664380910977592

Flyvbjerg, B.; Holm, M. K. S.; Buhl, S. L. 2003. How common and how large are cost overruns in transport infrastructure projects?, Transport Reviews 23(1): 71-88. https://doi.org/10.1080/01441640309904

Frimponga, Y.; Oluwoyeb, J.; and Crawfordc, L. 2003. Causes of delay and cost overruns in construction of groundwater projects in a developing country: Ghana as a case study, International Journal of Project Management (21): 321-326. https://doi.org/10.1016/S0263-7863(02)00055-8

Fugar, K.; Agyakwah-Baah, B. 2010. Delays in building construction projects in Ghana, Australasian Journal of Construction Economics and Building (10): 103-116.

Gunduz, M.; AbuHassan, H. A. 2017. Mapping the industrial perception of delay data through importance rating, Arabian Journal for Science and Engineering 42(9): 3799-3808.

https://doi.org/10.1007/s13369-017-2477-3

Harisaweni, H. 2007. "The Framework for Minimizing Construction Time and Cost Overruns in Padang and Pekanbaru, Indonesia": Master Thesis. Faculty of Built Environment, University of Technology, Malaysia.

Le-Hoai, L.; Lee, Y. D.; Lee, J. Y. 2008. Delay and cost overruns in Vietnam large construction projects: a comparison with other selected countries, KSCE Journal of Civil Engineering 12(6): 367-377. https://doi.org/10.1007/s12205-008-0367-7 
Lo, T. Y.; Fung, I.; Tung, K. 2006. Construction delays in Hong Kong civil engineering projects, Journal of Construction Engineering and Management 132(6): 636-649. https://doi.org/10.1061/(ASCE)0733-9364(2006)132:6(636)

Long, N. D.; S. Ogunlana, S.; Quang, T.; Lam, K. C. 2004. Large construction projects in developing countries: a case study from Vietnam, International Journal of Project Management (22): 553-561. https://doi.org/10.1016/j.ijproman.2004.03.004

Moura, H. P.; Teixeira, J. C.; Pires, B. 2007. Dealing with cost and time in the Portuguese construction industry, in Proceedings of the CIB World Building Congress, 14-18 May 2007, Cape Town South Africa, 1252-1265.

Odeh, A.; Battaineh, H. 2002. Causes of construction delays: traditional contracts, International Journal of Project Management 20(1): 67-73. https://doi.org/10.1016/S0263-7863(00)00037-5

Oludolapo, O. 2011. Mathematical expressions for explaining project delays in Southwestern Nigeria, Singapore Journal of Scientific Research 1(1): 59-67.

Omoregie, A. 2006. Infrastructure delays and cost escalation: causes and effects in Nigeria, in 6th International Postgraduate Research Conference in the Built and Human environment (2): 79-93.

Sambasivan, M.; Soon, Y. W. 2007. Causes and effects of delays in Malaysian construction industry, International Journal of Project Management 25(5): 517-526. https://doi.org/10.1016/j.ijproman.2006.11.007

Shibani, A.; Arumugam, K. 2015. Avoiding cost overruns in construction projects in India, Journal of Management Studies 3(7-8): 192-202.

Sinesilassie, E. G.; Tabish, S. Z. S.; Jha, K. N. 2017. Critical factors affecting cost performance: a case of Ethiopian public construction projects, International Journal of Construction Management 18(2): 108-119. https://doi.org/10.1080/15623599.2016.1277058

Sweis, G.; Sweis, R.; Abu Hammad, A.; Shboul, A. 2008. Delays in construction projects: the case of Jordan, International Journal of Project Management 26(6): 665-674. https://doi.org/10.1016/j.ijproman.2007.09.009

Tumi, S.; Omran, A.; Pakir, A. 2009. Causes of delay in construction industry in Libya, in The International Conference on Administration and Business. Faculty of Administration and Business, University of Bucharest, Romania, ICEA-FAA Bucharest, 14-15 November 2009, Bucharest, Romania, 265-272.

Yates, J. 1993. Construction decision support system for delay analysis, Journal of Construction Engineering and Management 119(2): 226-244. https://doi.org/10.1061/(ASCE)0733-9364(1993)119:2(226)

Yousefi, V.; Yakchali, S. H.; Khanzadi, M.; Mehrabanfar, E.; Šaparauskas, J. 2016. Proposing a neural network model to predict time and cost claims in construction projects, Journal of Civil Engineering and Management 22(7): 967-978. https://doi.org/10.3846/13923730.2016.1205510 